\title{
Mass transfer effects in hygroscopic measurements of aerosol particles
}

\author{
M. N. Chan ${ }^{1}$ and C. K. Chan ${ }^{2}$ \\ ${ }^{1}$ Environmental Engineering Program, School of Engineering, Hong Kong Univ. of Science and Technology, Clear Water \\ Bay, Kowloon, Hong Kong \\ ${ }^{2}$ Department of Chemical Engineering, Hong Kong Univ. of Science and Technology, Clear Water Bay, Kowloon, Hong Kong
}

Received: 2 May 2005 - Published in Atmos. Chem. Phys. Discuss.: 22 June 2005

Revised: 16 September 2005 - Accepted: 23 September 2005 - Published: 18 October 2005

\begin{abstract}
The tandem differential mobility analyzer (TDMA) has been widely utilized to measure the hygroscopicity of laboratory-generated and atmospheric submicrometer particles. An important concern in investigating the hygroscopicity of the particles is if the particles have attained equilibrium state in the measurements. We present a literature survey to investigate the mass transfer effects in hygroscopicity measurements. In most TDMA studies, a residence time in the order of seconds is used for humidification (or dehumidification). $\mathrm{NaCl}$ and $\left(\mathrm{NH}_{4}\right)_{2} \mathrm{SO}_{4}$ particles are usually used to verify the equilibrium measurements during this residence time, which is presumed to be sufficient for other particles. There have been observations that not all types of submicrometer particles, including atmospheric particles, attain their equilibrium sizes within this time scale. We recommend that experimentation with different residence times be conducted and that the residence time should be explicitly stated in future TDMA measurements. Mass transfer effects may also exist in the measurements of other properties related to the water uptake of atmospheric particles such as relative humidity dependent light scattering coefficients and cloud condensation nuclei activity.
\end{abstract}

\section{Introduction}

Atmospheric particles play an important role in the global climate change and in the chemistry of the troposphere. Determining the phase (solid or liquid) and size of atmospheric particles at different relative humidities $(\mathrm{RH})$ and temperatures is important for elucidating the role of atmospheric particles in many atmospheric processes such as the absorption and scattering of solar radiation (Martin et al., 2004), heterogeneous reactions between gas molecules and particles $(\mathrm{Hu}$

Correspondence to: C. K. Chan

(keckchan@ust.hk) and Abbatt, 1997), and cloud condensation nuclei (CCN) activity (Bilde and Svenningsson, 2004; Hartz et al., 2005 ${ }^{1}$ ).

The hygroscopicity of aerosol particles is commonly reported in terms of particle size (or mass) changes as a function of RH under saturation conditions. The aerosol water content is obtained by comparing the wet and dry particle sizes (or masses). When deliquescence (solid to liquid) or crystallization (liquid to solid) phase transitions occur, a spontaneous sharp change in particle size arises. Hygroscopicity data are useful in parameterizing thermodynamic models (Chan et al., 1997; Clegg et al., 1997, 2003; Ming and Russell, 2003; Topping et al., 2004) and revealing the state of the mixing of atmospheric particles (Cocker et al., 2001a). They are also needed for modeling the physicochemical properties of atmospheric particles, including their roles in global radiative forcing (Martin, 2000) and CCN activity (Rissler et al., 2004; Kreidenweis et al., 2005).

Most hygroscopicity measurements of aerosols, especially in field studies, are made with a tandem differential mobility analyzer (TDMA), also called Hygroscopic TDMA by some researchers (Liu et al., 1978; Rader and McMurry, 1986; McMurry and Stolzenburg, 1989; Swietlicki et al., 1999; Cruz and Pandis, 2000; Dick et al., 2000; Gysel et al., 2004). A key issue in investigating the hygroscopicity of the particles is if the particles have attained their equilibrium state in the measurements. In this paper, we conduct a survey in the literature on TDMA measurements (see Tables 1 and 2) and present evidence that hygroscopicity measurements can be potentially compromised by mass transfer effects attributed to the insufficient time allowed for particle growth or evaporation. We recommend that the residence time for humidification or dehumidification in TDMA studies be explicitly reported and that equilibrium measurements be confirmed.

\footnotetext{
${ }^{1}$ Hartz, K. E. H., Tischuk, J. E., Chan, M. N., Chan, C. K., Donahue, N. M., and Pandis, S. N.: Cloud condensation nuclei activation of limited solubility organic aerosol, Atmos. Environ., submitted, 2005.
} 
Table 1. Summary of Hygroscopic Measurement of Laboratory Generated Particles Utilizing the TDMA.

\begin{tabular}{|c|c|c|c|c|}
\hline Study & Chemical species studied & $\begin{array}{l}\text { Residence } \\
\text { time }(\mathrm{s})^{a}\end{array}$ & Initial particle size $(\mathrm{nm})^{b}$ & $\begin{array}{l}\text { Growth or evaporation } \\
\text { (Range of RH studied) }\end{array}$ \\
\hline \multicolumn{5}{|c|}{ Organic compounds or mixtures of an inorganic salt and an organic compound } \\
\hline Brooks et al. (2004) & $\begin{array}{l}\text { Fluka fulvic acid (FA), Pahokee peat reference humic acid (HA), } \\
\text { Leonardite standard HA, Suwannee river reference FA, Phthalic } \\
\text { acid, Polyacrylic acid, Their mixtures with }\left(\mathrm{NH}_{4}\right)_{2} \mathrm{SO}_{4}\end{array}$ & & $50,100,200$ & Growth $(15-95 \% \mathrm{RH})$ \\
\hline Gysel et al. (2004) & $\begin{array}{l}\text { Water soluble matters and humic-like substances isolated from } \\
\text { PM1.5 aerosol samples, Nordic reference fulvic and humic acids }\end{array}$ & 8 & 103 & Growth and Evaporation $(5-90 \% \mathrm{RH})$ \\
\hline Johnson et al. (2004) & $\begin{array}{l}\text { Di-2-ethylhexyl-sebacate (DEHS), Methanesulphonic acid } \\
\text { (MSA), }\left(\mathrm{NH}_{4}\right)_{2} \mathrm{SO}_{4}-\mathrm{MSA}, \mathrm{NaCl} \text { seeded DEHS }\end{array}$ & 13.4 & 100 & Growth $(90 \% \mathrm{RH})$ \\
\hline Mikhailov et al. (2004) & $\begin{array}{l}\text { Protein bovine serum albumin (BSA), NaCl-BSA, } \\
\left(\mathrm{NH}_{4}\right) \mathrm{NO}_{3}-\mathrm{BSA}\end{array}$ & $7.5-18.5$ & $100-201$ & Growth and Evaporation $(<5-95 \% \mathrm{RH})$ \\
\hline Mochida and Kawamura, (2004) & $\begin{array}{l}\text { Levoglucosan, D-Glucose, Vanillic, Syringic, } \\
\text { 4-hydroxybenozoic acids }\end{array}$ & & 100 & Growth $(5-95 \% \mathrm{RH})$ \\
\hline Sjogren et al. (2004) & Adipic acid, $\left(\mathrm{NH}_{4}\right)_{2} \mathrm{SO}_{4}-$ adipic acid & $1-120$ & & Growth $(10-90 \% \mathrm{RH})$ \\
\hline Prenni et al. (2003) & $\begin{array}{l}\left(\mathrm{NH}_{4}\right)_{2} \mathrm{SO}_{4}-\text { oxalic acid, }\left(\mathrm{NH}_{4}\right)_{2} \mathrm{SO}_{4}-\text { malonic acid, } \\
\left(\mathrm{NH}_{4}\right)_{2} \mathrm{SO}_{4}-\text { succinic acid, }\left(\mathrm{NH}_{4}\right)_{2} \mathrm{SO}_{4}-\text { glutaric acid, } \\
\left(\mathrm{NH}_{4}\right)_{2} \mathrm{SO}_{4} \text { - adipic acid }\end{array}$ & & 100 & Growth $(30-95 \% \mathrm{RH})$ \\
\hline Hameri et al. (2002) & $\begin{array}{l}\text { Adipic acid, Phthalic acid, }\left(\mathrm{NH}_{4}\right)_{2} \mathrm{SO}_{4} \text {-adipic acid, } \\
\left(\mathrm{NH}_{4}\right)_{2} \mathrm{SO}_{4} \text {-phthalic acid, }\left(\mathrm{NH}_{4}\right)_{2} \mathrm{SO}_{4} \text {-succinic acid, } \\
\left(\mathrm{NH}_{4}\right)_{2} \mathrm{SO}_{4} \text {-malonic acid }\end{array}$ & 4.4 & 100 & Growth $(50-90 \% \mathrm{RH})$ \\
\hline Prenni et al. (2001) & $\begin{array}{l}\text { Oxalic acid, Malonic acid, Succinic acid, Glutaric acid, } \\
\text { Adipic acid }\end{array}$ & & 50,100 & Growth $(45-95 \% \mathrm{RH})$ \\
\hline Cruz and Pandis (2000) & $\begin{array}{l}\text { Glutaric acid, Pinonic acid, } \\
\text { NaCl-glutaric acid, }\left(\mathrm{NH}_{4}\right)_{2} \mathrm{SO}_{4} \text {-glutaric acid, } \\
\mathrm{NaCl} \text {-pinonic acid, }\left(\mathrm{NH}_{4}\right)_{2} \mathrm{SO}_{4} \text {-pinonic acid }\end{array}$ & 30 & $50,80,100$ & Growth $(35-95 \% \mathrm{RH})$ \\
\hline Chen and Lee (1999) & $\begin{array}{l}\text { Sodium oleate, Tween } 80, \text { Span } 80 \text {, } \\
\text { Sodium dedecyl sulfate (SDS), } \\
\text { CaCl- Sodium oleate, CaCl-Tween } 80 \text {, } \\
\text { CaCl-Span } 80, \mathrm{CaCl}-\mathrm{SDS}\end{array}$ & 15 & 74 & Growth $(7-85 \% \mathrm{RH})$ \\
\hline \multicolumn{5}{|c|}{ Inorganic Salt and Mixtures of Inorganic salts } \\
\hline $\begin{array}{l}\text { Johnson et al. (2004) } \\
\text { Mikhailov et al. (2004) } \\
\text { Sjogren et al. (2004) } \\
\text { Pagels et al. (2003) } \\
\text { Gysel et al. (2002) } \\
\text { Hameri et al. (2001a) } \\
\text { Brechtel and Kreidenweis (2000) } \\
\text { Cruz and Pandis (2000) } \\
\text { Hameri et al. (2000) } \\
\text { Hansson et al. (1998) } \\
\text { Ristovski et al. (1998) } \\
\text { Xiong et al. (1998) }\end{array}$ & $\begin{array}{l}\mathrm{NaCl},\left(\mathrm{NH}_{4}\right)_{2} \mathrm{SO}_{4}, \mathrm{NaNO}_{3}, \mathrm{NH}_{4} \mathrm{HSO}_{4}, \mathrm{H}_{2} \mathrm{SO}_{4} \\
\mathrm{NaCl},\left(\mathrm{NH}_{4}\right) \mathrm{NO}_{3} \\
\left(\mathrm{NH}_{4}\right)_{2} \mathrm{SO}_{4} \\
\mathrm{~K}_{2} \mathrm{SO}_{4}, \mathrm{~K}_{2} \mathrm{CO}_{3} \\
\mathrm{NaCl},\left(\mathrm{NH}_{4}\right)_{2} \mathrm{SO}_{4}, \mathrm{NaNO}_{3} \\
\mathrm{NaCl} \\
\mathrm{NaCl},\left(\mathrm{NH}_{4}\right)_{2} \mathrm{SO}_{4}, \mathrm{NH}_{4} \mathrm{HSO}_{4}, \mathrm{NaCl}\left(\mathrm{NH}_{4}\right)_{2} \mathrm{SO}_{4} \\
\mathrm{NaCl},\left(\mathrm{NH}_{4}\right)_{2} \mathrm{SO}_{4} \\
\left(\mathrm{NH}_{4}\right)_{2} \mathrm{SO}_{4} \\
\mathrm{NaCl} \\
\mathrm{NaCl} \\
\mathrm{H}_{2} \mathrm{SO}_{4}\end{array}$ & $\begin{array}{l}13.4 \\
7.5-18.5 \\
1-120 \\
60\end{array}$ & $\begin{array}{l}100 \\
100-201 \\
100 \\
100 \\
8-50 \\
25-102 \\
50,80,100 \\
8-50 \\
50,100,200 \\
50 \\
40-120\end{array}$ & $\begin{array}{l}\text { Growth }(90 \% \mathrm{RH}) \\
\text { Growth and Evaporation }(<5-95 \% \mathrm{RH}) \\
\text { Growth }(10-90 \% \mathrm{RH}) \\
\text { Growth }(25-90 \% \mathrm{RH}) \\
\text { Growth and Evaporation }(5-95 \% \mathrm{RH}) \\
\text { Growth and Evaporation }(<5-90 \% \mathrm{RH}) \\
\text { Growth (35-95\%RH) } \\
\text { Growth and Evaporation ( }<5 \%-90 \mathrm{RH}) \\
\text { Growth and Evaporation }(30-90 \% \mathrm{RH}) \\
\text { Growth }(50-\sim 100 \% \mathrm{RH}) \\
\text { Growth }(20-85 \% \mathrm{RH})\end{array}$ \\
\hline \multicolumn{5}{|l|}{$\underline{\text { Soot Particles }}$} \\
\hline $\begin{array}{l}\text { Gysel et al. (2003) } \\
\text { Pagels et al. (2003) } \\
\text { Dua et al. (1999) } \\
\text { Weingartner et al. (1997) }\end{array}$ & $\begin{array}{l}\text { Source: Jet engine combustor } \\
\text { Source: Moving gate boiler } \\
\text { Source: Resident wood stove } \\
\text { Source: Diesel engines }\end{array}$ & $2.2-10$ & $\begin{array}{l}30,50,100 \\
35-350 \\
30-250 \\
51.5,73,108\end{array}$ & $\begin{array}{l}\text { Growth }(70-90 \% \mathrm{RH}) \\
\text { Growth }(25-90 \% \mathrm{RH}) \\
\text { Growth }(>99 \% \mathrm{RH}) \\
\text { Growth }(>99 \% \mathrm{RH})\end{array}$ \\
\hline \multicolumn{5}{|l|}{ Smokes particles } \\
\hline Dua and Hopke (1996) & $\begin{array}{l}\text { Source: different kind of oil during deep frying, sausages during } \\
\text { grilling, burning wood in a stoves }\end{array}$ & & $50-325$ & Growth $(\sim 100 \% \mathrm{RH})$ \\
\hline \multicolumn{5}{|l|}{ Organic Coating } \\
\hline $\begin{array}{l}\text { Hansson et al. (1998) } \\
\text { Xiong et al. (1998) }\end{array}$ & $\begin{array}{l}\mathrm{NaCl} \text { coated with tetracosane acid, octanoic acid, lauric acid } \\
\mathrm{H}_{2} \mathrm{SO}_{4} \text { coated with lauric acid, stearic acid, oleic acid }\end{array}$ & $\begin{array}{l}10-20 \\
6-10\end{array}$ & $\begin{array}{l}50,100,200 \\
40-120\end{array}$ & $\begin{array}{l}\text { Growth and Evaporation }(30-85 \mathrm{RH}) \\
\text { Growth }(20-85 \% \mathrm{RH})\end{array}$ \\
\hline \multicolumn{5}{|l|}{ Secondary Organic Aerosols (SOA) } \\
\hline Saathoff et al. (2003) & $\begin{array}{l}\text { SOA formed from ozonolysis of } \alpha \text {-pinene } \\
\text { (Diesel soot, }\left(\mathrm{NH}_{4}\right)_{2} \mathrm{SO}_{4} \text { as seed particles) }\end{array}$ & & 100,200 & Growth and Evaporation (15-90\%RH) \\
\hline Cocker et al. (2001b) & $\begin{array}{l}\text { SOA formed from ozonolysis of } \alpha \text {-pinene } \\
\left(\mathrm{CaCl}_{2},\left(\mathrm{NH}_{4}\right)_{2} \mathrm{SO}_{4},\left(\mathrm{NH}_{4}\right) \mathrm{HSO}_{4} \text { as seed particles }\right)\end{array}$ & 10 & 136,235 & Growth $(5-89 \% \mathrm{RH})$ \\
\hline Cocker et al. (2001c) & $\begin{array}{l}\text { SOA formed from ozonolysis of m-xylene } \\
\text { and } 1,3,5 \text {-trimethylbenzene } \\
\left(\left(\mathrm{NH}_{4}\right) \mathrm{HSO}_{4} \text { as seed particles }\right)\end{array}$ & $\begin{array}{l}10 \\
\text { refer to } \\
\text { Cocker et al. (2001b) }\end{array}$ & 136,235 & Growth $(85 \% \mathrm{RH})$ \\
\hline Virkkula et al. (1999) & $\begin{array}{l}\text { SOA formed from oxidation of } \alpha \text {-pinene, } \\
\beta \text {-pinene, and limonene } \\
\left(\left(\mathrm{NH}_{4}\right)_{2} \mathrm{SO}_{4} \text { as seed particles }\right)\end{array}$ & 2.4 & $30-200$ & Growth $(81-87 \% \mathrm{RH})$ \\
\hline
\end{tabular}

$a$ The residence time of the submicrometer particles in a RH conditioner (humidifier or dehumidifier). ${ }^{b}$ Particle size selected by the first DMA. 
Table 2. Summary of Hygroscopic Measurement of Atmospheric Particles Utilizing the TDMA.

\begin{tabular}{|c|c|c|c|c|c|}
\hline Study & Sampling Period and Location & Residence Time $(\mathrm{s})^{a}$ & Chemical Species ${ }^{b}$ & $\begin{array}{l}\text { Initial Particle Size }(\mathrm{nm})^{c} \\
(\mathrm{RH} \text { in the dryer) }\end{array}$ & $\begin{array}{l}\text { Growth or Evaporation } \\
\text { (Range of RH Studied) }\end{array}$ \\
\hline Carrico et al. (2005) & $\begin{array}{l}\text { July-September, 2002, Yosemite National } \\
\text { Park, California, U.S. }\end{array}$ & $\sim 2.5$ & $\left(\mathrm{NH}_{4}\right)_{2} \mathrm{SO}_{4}$ & $\begin{array}{l}\text { 100, } 200 \\
\text { (drying RH: }<5 \% \mathrm{RH} \text { ) }\end{array}$ & Growth $(40-90 \% \mathrm{RH})$ \\
\hline Ferron et al. (2005) & $\begin{array}{l}\text { Winter, summer and fall, 1998, Bavaria, } \\
\text { Germany }\end{array}$ & & $\mathrm{NaCl}$ & $50,100,150,250$ & Growth $(85 \% \mathrm{RH})$ \\
\hline Santarpia et al. (2005) & August and September, 2002, Texas, U.S. & & $\mathrm{NaCl}$ & $\begin{array}{l}\text { 12-400 } \\
\text { (drying RH: } 20 \% R H \text { ) }\end{array}$ & Growth and Evaporation (30-85\%RH) \\
\hline Aklilu and Mozurkewich (2004) & August, 2001, British Columbia, Canada & & $\left(\mathrm{NH}_{4}\right)_{2} \mathrm{SO}_{4}$ & $\begin{array}{l}50,80,114,160 \\
\text { (drying RH: } 15 \% \mathrm{RH})\end{array}$ & Growth $(50-85 \% \mathrm{RH})$ \\
\hline Gasparini et al. (2004) & June-October, 2001, Texas, U.S. & & $\mathrm{NaCl}$ & $\begin{array}{l}25-344 \\
\text { (drying RH: } 20 \% \mathrm{RH} \text { ) }\end{array}$ & Growth $(84 \% \mathrm{RH})$ \\
\hline Rissler et al. (2004) & July, 2001, Balbina, Amazonia, Brazil & & $\left(\mathrm{NH}_{4}\right)_{2} \mathrm{SO}_{4}$ & (drying RH: $\mathrm{RH}<10 \%$ ) & Growth $(90 \% \mathrm{RH})$ \\
\hline Santarpia et al. (2004) & August, 2002, Texas, U.S. & & $\mathrm{NaCl}$ & $\begin{array}{l}\text { 160, } 320 \\
\text { (drying RH: } 20 \% \mathrm{RH} \text { ) }\end{array}$ & Growth and Evaporation (30-85\%RH) \\
\hline Chen et al. (2003) & October-December, 2001, Taipei, Taiwan & 6 & $\mathrm{NaCl},\left(\mathrm{NH}_{4}\right)_{2} \mathrm{SO}_{4}$ & $\begin{array}{l}53,82,95,202 \\
\text { (drying RH: <20\%RH) }\end{array}$ & Growth (60-90\%RH) \\
\hline Massling et al. (2003) & $\begin{array}{l}\text { January-February, 1999, Atlantic Ocean and } \\
\text { February-March, 1999, Indian Ocean }\end{array}$ & & $\begin{array}{l}\mathrm{NaCl}, \\
\left(\mathrm{NH}_{4}\right)_{2} \mathrm{SO}_{4} \\
\mathrm{KCl}\end{array}$ & $\begin{array}{l}50,150,250 \\
\text { (drying } \mathrm{RH}:<5 \% \mathrm{RH} \text { ) }\end{array}$ & Growth $(30,55,75,90 \% \mathrm{RH})$ \\
\hline Baltensperger et al. (2002) & May-June, 1998, Bresso, Milan, Italy & $\begin{array}{l}60 \text { refer to Weingart- } \\
\text { ner et al. }(2002)\end{array}$ & & $\begin{array}{l}\text { 50-200 } \\
\text { (drying RH: }<30 \% \mathrm{RH})\end{array}$ & Growth $(90 \% \mathrm{RH})$ \\
\hline Busch et al. (2002) & July-August, Falkenberg, Berlin, Germany & & $\mathrm{NaCl}$ & $50,100,150,250$ & Growth (60 and $90 \% \mathrm{RH})$ \\
\hline Buzorius et al. (2002) & Cheju Island, Republic of South Korea & & $\left(\mathrm{NH}_{4}\right)_{2} \mathrm{SO}_{4}$ & 250 & Growth $(>90 \% \mathrm{RH})$ \\
\hline Roberts et al. (2002) & March-April, 1998, Amazonia, Brazil & & $\mathrm{NaCl},\left(\mathrm{NH}_{4}\right)_{2} \mathrm{SO}_{4}$ & $\begin{array}{l}\text { 35-264 } \\
\text { (drying RH: }<10 \% \mathrm{RH} \text { ) }\end{array}$ & Growth (70 and $90 \% \mathrm{RH})$ \\
\hline Vakeva et al. (2002a) & $\begin{array}{l}\text { 1997-1999, Helsinki, Luukki, Hyytiala, } \\
\text { Finland and Western Ireland }\end{array}$ & & $\left(\mathrm{NH}_{4}\right)_{2} \mathrm{SO}_{4}$ & 10,20 & Growth $(90 \% \mathrm{RH})$ \\
\hline Vakeva et al. (2002b) & $\begin{array}{l}\text { September, 1998, and June, 1999, } \\
\text { west coast of Ireland }\end{array}$ & & $\left(\mathrm{NH}_{4}\right)_{2} \mathrm{SO}_{4}$ & $8-20$ & Growth $(90 \% \mathrm{RH})$ \\
\hline Weingartner et al. (2002) & March, 2000, Jungfraujoch, Switzerland & 60 & $\left(\mathrm{NH}_{4}\right)_{2} \mathrm{SO}_{4}$ & $\begin{array}{l}50,100,250 \\
\text { (drying RH: }<15 \% \mathrm{RH} \text { ) }\end{array}$ & Growth $(10-85 \% \mathrm{RH})$ \\
\hline Zhou et al. (2002) & March-April, 1998, Amazonia, Brazil & & $\mathrm{NaCl},\left(\mathrm{NH}_{4}\right)_{2} \mathrm{SO}_{4}$ & $\begin{array}{l}35-264 \\
\text { (drying RH: }<5 \% \mathrm{RH} \text { ) }\end{array}$ & Growth $(90 \% \mathrm{RH})$ \\
\hline Cocker et al. (2001a) & $\begin{array}{l}\text { August-September, 1999, } \\
\text { Pasadena, California, U.S. }\end{array}$ & & & $\begin{array}{l}50,150 \\
\text { (drying } \mathrm{RH}<10 \% \mathrm{RH} \text { ) }\end{array}$ & Growth $(89 \% \mathrm{RH})$ \\
\hline Zhou et al. (2001) & July-August, 1996, Arctic Ocean & & $\mathrm{NaCl}$ & $\begin{array}{l}15,35,50,165 \\
\text { (drying RH: }<10 \% \mathrm{RH} \text { ) }\end{array}$ & Growth $(50,70,90 \% \mathrm{RH})$ \\
\hline Dick et al. (2000) & $\begin{array}{l}\text { July-August, 1995, Great Smoky Mountain } \\
\text { National Park, U.S. }\end{array}$ & $1.3-5.0$ & & $\begin{array}{l}\text { 50, 100, 200, 300, } 400 \\
\text { (drying RH: } \sim 5 \% \mathrm{RH} \text { ) }\end{array}$ & Growth $(5-85 \% \mathrm{RH})$ \\
\hline Swietlicki et al. (2000) & $\begin{array}{l}\text { June-July, } 1997,5 \text { sites in the subtropical North } \\
\text { Eastern Atlantic }\end{array}$ & $1-2$ & $\mathrm{NaCl},\left(\mathrm{NH}_{4}\right)_{2} \mathrm{SO}_{4}$ & $\begin{array}{l}\text { 35-440 } \\
\text { (drying RH: <10\%RH) }\end{array}$ & Growth $(<10 \%-90 \% \mathrm{RH})$ \\
\hline Swietlicki et al. (1999) & March-April, 1995, Great Dun Fell, England & & $\mathrm{NaCl}$ & $\begin{array}{l}35-265 \\
\text { (drying RH: }<10 \% \mathrm{RH})\end{array}$ & Growth $(90 \% \mathrm{RH})$ \\
\hline Berg et al. (1998) & $\begin{array}{l}\text { October-November, 1995, Pacific Ocean } \\
\text { November-December, 1995, Southern Ocean }\end{array}$ & & $\mathrm{NaCl},\left(\mathrm{NH}_{4}\right)_{2} \mathrm{SO}_{4}$ & $\begin{array}{l}35-165 \\
\text { (DMA1: <10\%RH) }\end{array}$ & $\begin{array}{l}\text { Growth }(89 \text { or } 90 \% \mathrm{RH}) \\
\text { Evaporation }(50,60 \% \mathrm{RH})\end{array}$ \\
\hline Covert et al. (1998) & $\begin{array}{l}\text { November and December, 1995, Cape Grim, } \\
\text { Tasmania }\end{array}$ & & & $\begin{array}{l}\text { 30, } 50,150,250 \\
\text { (drying RH: } \sim 25 \% \mathrm{RH} \text { ) }\end{array}$ & Growth $(90 \% \mathrm{RH})$ \\
\hline Svenningsson et al. (1997) & April and May, 1993, Great Dun Fell, England & & $\mathrm{NaCl},\left(\mathrm{NH}_{4}\right)_{2} \mathrm{SO}_{4}$ & $\begin{array}{l}50,75,110,165,265 \\
\text { (drying RH: }<20 \% \mathrm{RH} \text { ) }\end{array}$ & Growth $(90 \% \mathrm{RH})$ \\
\hline McMurry et al. (1996) & September, 1994, Minneapolis, U.S. & & & $\begin{array}{l}\text { 300-400 } \\
\text { (drying RH: } 48 \% \mathrm{RH})\end{array}$ & Growth (87\%RH) \\
\hline Saxena et al. (1995) & Grand Canyon and Los Angeles, U.S. & $\begin{array}{l}1.3-5.0 \text { refer to Mc- } \\
\text { Murry and Stolzen- } \\
\text { burg (1989) }\end{array}$ & $\begin{array}{l}\mathrm{NaCl}, \\
\mathrm{H}_{2} \mathrm{SO}_{4}, \\
\left(\mathrm{NH}_{4}\right)_{2} \mathrm{SO}_{4}\end{array}$ & $\begin{array}{l}\text { 16-500 } \\
\text { (drying RH: ambient RH) }\end{array}$ & Growth (80-93\%RH) \\
\hline Pitchford and McMurry (1994) & $\begin{array}{l}\text { January-March, 1990, Grand Canyon National } \\
\text { Park, Arizona, U.S. }\end{array}$ & & & $15-400$ & Growth (3-90\%RH) \\
\hline Svenningsson et al. (1994) & $\begin{array}{l}\text { October and November, 1990, } \\
\text { Kleiner Feldberg, Taunus, Germany }\end{array}$ & & & $\begin{array}{l}\text { 50, 150, 300 } \\
\text { (DMA1: } \sim 10-20 \% \mathrm{RH})\end{array}$ & Growth $(<20-85 \%$ RH $)$ \\
\hline Covert and Heintzenberg (1993) & March and April, 1989, Ny Alesund, Svalbard & & $\left(\mathrm{NH}_{4}\right)_{2} \mathrm{SO}_{4}$ & $\begin{array}{l}\text { 110, 200, } 310 \\
\text { (DMA1: } 20 \% \mathrm{RH})\end{array}$ & Growth (90\%RH) \\
\hline Zhang et al. (1993) & $\begin{array}{l}1987 \text { and 1990, Claremont, Los Angeles and } \\
\text { Grand Canyon, U.S. }\end{array}$ & $\begin{array}{l}1.3-5.0 \text { refer to Mc- } \\
\text { Murry and Stolzen- } \\
\text { burg (1989) }\end{array}$ & $\begin{array}{l}\mathrm{NaCl}, \mathrm{H}_{2} \mathrm{SO}_{4} \\
\left(\mathrm{NH}_{4}\right)_{2} \mathrm{SO}_{4}\end{array}$ & $\begin{array}{l}\text { 15-400 } \\
\text { (drying RH: ambient RH) }\end{array}$ & Growth (3-90\%RH) \\
\hline Svenningsson et al. (1992) & November, 1989 Po Valley, Italy & & $\mathrm{NaCl},\left(\mathrm{NH}_{4}\right)_{2} \mathrm{SO}_{4}$ & $30,50,100,150,200$ & Growth (85\%RH) \\
\hline McMurry and Stolzenburg (1989) & $\begin{array}{l}\text { June and September, 1987, Claremont, } \\
\text { Los Angeles, U.S. }\end{array}$ & $1.3-5.0$ & $\begin{array}{l}\mathrm{NaCl}, \mathrm{H}_{2} \mathrm{SO}_{4} \\
\left(\mathrm{NH}_{4}\right)_{2} \mathrm{SO}_{4}\end{array}$ & $\begin{array}{l}\text { 50, 200, } 500 \\
\text { (drying RH: ambient RH) }\end{array}$ & Growth $(7-90 \% \mathrm{RH})$ \\
\hline
\end{tabular}

$a$ The residence time of the submicrometer particles in a RH conditioner (humidifier or dehumidifier). ${ }^{b}$ Chemical species used to check the performance of the TDMA system. ${ }^{c}$ Particle size selected by the first DMA. It is noted that atmospheric aerosols are dried in the first DMA instead of diffusion dryer in some studies. The drying RH is the RH inside the dryer unless specified otherwise. 


\section{Measurement techniques}

TDMA and the electrodynamic balance (EDB) (Richardson and Spann, 1984; Cohen et al., 1987; Ray et al., 1989; Chan et al., 1992; Tang and Munkelwitz, 1993, 1994; Chan and Chan, 2003) are the most commonly used techniques for hygroscopicity measurements and their measurements are often compared. Comprehensive summaries of previous laboratory studies have been presented by Martin (2000) and Kanakidou et al. (2005). A summary of laboratory TDMA studies has been presented in Table 1. Other techniques include single particle mass spectrometry (Ge et al., 1996, 1998), ambient-dry aerosol size spectrometer (Stanier et al., 2004), RH-controlled nephelometry (ten Brink et al., 2000), aerosol cell-microscope system (Pant et al., 2004; Parsons et al., 2004), aerosol flow tube-Fourier Transform Infrared (FTIR) system (Brooks et al., 2003; Braban and Abbatt, 2004), RHcontrolled optical particle counter (Ames et al., 2000; Hand et al., 2000; Kreisberg et al., 2001), filter-based analysis by beta attenuation (or gravitational method) (Hitzenberger et al., 1997; Speer et al., 1997), and water activity measurements of bulk aqueous solutions (Brooks et al., 2002; Wise et al., 2003; Marcolli et al., 2004).

We focus our discussions on TDMA measurements in this paper. A typical TDMA system consists of a diffusion dryer, two differential mobility analyzers (DMA), an RH conditioner (humidifier or dehumidifier) set between the two DMA, and a condensation particle counter (CPC). Initially, atmospheric (or laboratory-generated) polydispersed particles are dried in a diffusion dryer. Monodispersed particles (a few to hundreds of nanometers in mobility diameter) selected by a DMA are then passed through the RH conditioner, in which humidification of the particles takes place. The size of the particles leaving the RH conditioner is measured with the other DMA and the CPC (Rader and McMurry, 1986; McMurry and Stolzenburg, 1989). Different configurations of TDMA systems have been employed in atmospheric aerosol studies (Chuang, 2003; Santarpia et al., 2004). The TDMA reports the relative change in the particle mobility diameter or the growth factor, $G_{f}$, which is the ratio of the particle diameter at a high $\mathrm{RH}$ to a dry particle diameter at reference $\mathrm{RH}$, as a function of RH.

An EDB utilizes a combination of an alternating current electric field and a direct current electric field to levitate single particles (Davis, 1997). A charged particle can be levitated and kept stationary when the electrostatic force it experiences balances its weight. Hence, relative mass measurements due to humidity changes can be made by adjusting the DC voltage required to make the particle stationary. In hygroscopicity measurements, the measurements of a particle under multiple stepwise increases (or decreases) in RH and the mass of the particle is determined as a function of RH. Data in terms of the mass ratio or the mass fraction of the solute are reported at different RH. The data can be converted to $G_{f}$ (or vice versa) with the determination of the particle density for comparison with the TDMA measurements. In contrast to the TDMA, the EDB measures the hygroscopicity of the particles that are few to tens of $\mu \mathrm{m}$ in diameter and it can only measure laboratory-generated particles.

\section{Equilibrium measurement}

Theoretical analysis of the gas-particle equilibrium time scales for the water uptake for a non-volatile particle is available in the literature (Kerminen, 1997). In gas condensation, the flux of a species into a single particle, $I_{i}$, can be described by:

$I_{i}\left(d_{p}\right)=\frac{2 \pi D_{i}\left[C_{i}-C_{i, e q}\left(d_{p}\right)\right]}{1+2 \lambda / \alpha_{i} d_{p}}$

where $d_{p}$ is the particle diameter, $D_{i}$ is the gas-phase diffusion coefficient of the species, $i, C_{i}$ and $C_{i, e q}$ are its concentration in the gas phase and over the particle surface, respectively, $\lambda$ is the air mean free path, and $\alpha$ is the accommodation coefficient accounting for the imperfect accommodation of the species on the particle surface. Kerminen (1997) estimated the time required for the achievement of water equilibrium to be between $8 \times 10^{-6} \mathrm{~s}$ and $0.1 \mathrm{~s}$ for $100 \mathrm{~nm}$ and $500 \mathrm{~nm}$ particles at $90 \% \mathrm{RH}$ and at $0^{\circ} \mathrm{C}$ and $25^{\circ} \mathrm{C}$ with different accommodation coefficients (0.001 to 1$)$. The typical residence time of a few seconds in the $\mathrm{RH}$ conditioner in TDMA measurements is adequate for most equilibrium hygroscopic measurements. Significantly longer equilibrium time may be required when the accommodation coefficient is much less than 0.001. Chuang (2003) found that some atmospheric particles exhibited equilibrium time scale in the order of seconds to tens of seconds in their TDMA measurements. He estimated that the accommodation coefficients of these particles are in the range of $10^{-4}$ to $10^{-5}$. This falls into the lower range of values reported in laboratory experiments using model aerosols with single component films. Atmospheric particles containing organic films resulting in an accommodation coefficient in the range of $10^{-4}$ to $10^{-5}$ may not achieve equilibrium in TDMA experiments.

Most researchers choose $\mathrm{NaCl}$ or $\left(\mathrm{NH}_{4}\right)_{2} \mathrm{SO}_{4}$ particles to verify the time scale for equilibrium measurements with the implicit assumption that the water vapor-particle equilibrium is also achieved for other particles, including atmospheric particles, in the same time scale (order of seconds). However, in addition to possibility of having particles of a very low accommodation coefficient, transport effects in very viscous particles can also hinder gas-particle equilibrium (Seinfeld, 1986; Kerminen, 1997; Chan et al., 1998). Chan and coworkers have experimentally shown that the achievement of equilibrium of some aqueous droplets can be hindered by the transport limitation inside the droplets in their EDB measurements. For example, Chan et al. (2000) found that there is a significant retardation of water evaporation (and growth) 
rate of magnesium sulfate $\left(\mathrm{MgSO}_{4}\right)$ droplets at high concentrations (at low RH). Using Raman spectroscopy, Zhang and Chan (2000) attributed this delay to the formation of contact ion pairs and chain structures in highly concentrated droplets of $\mathrm{MgSO}_{4}$. Moreover, Peng et al. (2001) observed that glutaric acid particles took a significant longer time $(\sim 10 \mathrm{~h})$ to completely deliquesce, compared to other dicarboxylic acids and multifunctional acids particles ( $\sim 40 \mathrm{~min})$. This mass transfer limitation in the growth process was also observed in sodium pyruvate particles by Peng and Chan (2001). These significant retardations in growth or evaporation rates were not found for $\mathrm{NaCl}$ or $\left(\mathrm{NH}_{4}\right)_{2} \mathrm{SO}_{4}$ particles in their EDB measurements. Overall, mass transfer effects in hygroscopic measurements of ambient particles and laboratory generated particles are possible if the particles are not allowed to have sufficient time to achieve their equilibrium sizes in the $\mathrm{RH}$ conditioner. Residence time of a few seconds may not be adequate, depending on the nature of the particles.

\section{Mass transfer effects in the TDMA measurements}

\subsection{Laboratory measurements}

A number of hygroscopicity measurements of inorganic salt particles (e.g., $\mathrm{NaCl},\left(\mathrm{NH}_{4}\right)_{2} \mathrm{SO}_{4}$, and $\mathrm{NH}_{4} \mathrm{NO}_{3}$ ) using TDMA and EDB have been reported. There is a general agreement on the hygroscopicity of typical inorganic salt particles although some discrepancies between the data have been observed. For example, different crystallization characteristics of some supersaturated droplets (e.g., $\mathrm{NH}_{4} \mathrm{NO}_{3}$ ) have been attributed to the presence of impurities that may have heterogeneously seeded the crystallization (Martin, 2000).

The hygroscopicity of glutaric acid particles as a function of RH has been measured by Cruz and Pandis (2000) and Prenni et al. (2001) using TDMA and by Peng et al. (2001) using EDB. Cruz and Pandis (2000) reported a $G_{f}$ of approximately 1.10 at $90 \% \mathrm{RH}$. On the other hand, Prenni et al. (2001) reported a $G_{f}$ of 1.29 , which is close to a $G_{f}$ of 1.30 reported by Peng et al. (2001). Solute evaporation loss in semi-volatile glutaric acid particles, the Kelvin effect, and the shape factor in converting the mobility diameter to the geometric diameter do not account for the differences in the $G_{f}$. The results of Peng et al. (2001) and Prenni et al. (2001) were consistent with those inferred from the water activity measurements of aqueous glutaric acid solution after deliquescence, suggesting that the glutaric acid particles had reached their equilibrium sizes.

Furthermore, Peng et al. (2001) observed that glutaric acid particles continued to absorb water for several hours during deliquescence at $83-85 \% \mathrm{RH}$, which was much longer than the approximately $40 \mathrm{~min}$ required for other dicarboxylic acid particles (e.g., malonic acid) to reach their equilibrium sizes in their EDB measurements (the rather long equili- bration time in EDB measurements is because of the time required to change the $\mathrm{RH}$ inside the EDB). This observation suggested that glutaric acid particles exhibited a strong kinetic effect during deliquescence and required a longer equilibrium time than did inorganic salt and the other dicarboxylic acid particles they studied. Although Cruz and Pandis (2000) reported that $\mathrm{NaCl}$ and $\left(\mathrm{NH}_{4}\right)_{2} \mathrm{SO}_{4}$ particles attained their equilibrium sizes with residence times longer than $10 \mathrm{~s}$, the residence time of the glutaric acid particles was not tested. Peng et al. (2001) attributed the lower $G_{f}$ of glutaric acid particles reported by Cruz and Pandis (2000) after deliquescence to the mass transfer effects in the TDMA growth measurements. These observations suggest that the time required for $\mathrm{NaCl}$ and $\left(\mathrm{NH}_{4}\right)_{2} \mathrm{SO}_{4}$ particles to achieve their equilibrium sizes may not necessarily be sufficient for particles of other chemical systems, including possibly atmospheric particles.

Various studies have reported the dependence of $G_{f}$ of the particles on the residence time. Ristovski et al. (1998) observed that the $G_{f}$ of $\mathrm{NaCl}$ particles increased from approximately 1.1 to 1.9 at $90 \% \mathrm{RH}$ when the residence time increased from 2.2s to 7.4s. Cruz and Pandis (2000) reported that the $G_{f}$ of $\mathrm{NaCl}$ and $\left(\mathrm{NH}_{4}\right)_{2} \mathrm{SO}_{4}$ particles after humidification were independent of the residence time only when the residence time was longer than 10 s but not shorter. Sjogren et al. (2004) found that $\left(\mathrm{NH}_{4}\right)_{2} \mathrm{SO}_{4}$-adipic acid particles $\left(50 \mathrm{wt} \%\right.$ and $76 \mathrm{wt} \%$ adipic acid) exhibited a lower $G_{f}$ at a residence time of less than $4 \mathrm{~s}$ than the $G_{f}$ at more than $4 \mathrm{~s}$ at $78-91 \%$ RH after deliquescence.

Xiong et al. (1998) found that submicrometer sulfuric acid $\left(\mathrm{H}_{2} \mathrm{SO}_{4}\right)$ particles attained their equilibrium size within $6 \mathrm{~s}$. On the other hand, the $G_{f}$ of $\mathrm{H}_{2} \mathrm{SO}_{4}$ particles coated with three monolayers of lauric acid further increased as the residence time increased from $6 \mathrm{~s}$ to $10 \mathrm{~s}$, providing evidence that the coated $\mathrm{H}_{2} \mathrm{SO}_{4}$ particles had not yet reached their equilibrium size within $6 \mathrm{~s}$. Organic films can act a physical barrier to retard the water condensation (or evaporation) rate in planar solutions and on particle surfaces (Gill et al., 1983; Barnes, 1986) and can lower the accommodation coefficient (Pandis et al., 1995). A summary of laboratory studies on the evaporation and condensation rates of water vapor from particles in the presence of organic films has been presented by Chuang (2003).

\subsection{Field measurements}

Unlike for laboratory-generated particles, the chemical compositions of atmospheric particles are generally unknown a priori and comparison of measurements with literature data on the identified chemical systems is not practical. Previous studies on the hygroscopicity of atmosphere particles using TDMA have been summarized by Cocker et al. (2001a) and Kanakidou et al. (2005). These studies and more recent field studies are summarized in Table 2. The performance of the TDMA is usually checked by measuring the hygroscopicity 
of $\mathrm{NaCl}$ and $\left(\mathrm{NH}_{4}\right)_{2} \mathrm{SO}_{4}$ particles, whose hygroscopic properties $\left(G_{f}\right.$, deliquescence $\mathrm{RH}$, crystallization $\left.\mathrm{RH}\right)$ are well known. As can be seen in Table 2, the residence time of submicrometer atmospheric particles in the RH conditioner is usually not explicitly stated in the studies. The reported values are usually on the order of a few seconds $(<6 \mathrm{~s})$, which is often presumed to be sufficient to capture the hygroscopicity of atmospheric particles.

Chuang (2003) conducted an experiment in which atmospheric particles were humidified in two tandem humidifiers (instead of one in conventional TDMA measurements) to determine the equilibrium time scale of water uptake for atmospheric particles. He reported that most atmospheric particles reached their equilibrium sizes in less than $2 \mathrm{~s}$ to $3 \mathrm{~s}$ at $\sim 90 \% \mathrm{RH}$ during both the dry and wet seasons in Mexico City. On the other hand, a small number of atmospheric particles ( 0 to $2 \%$ depending on particle size and season) exhibited equilibrium time scales longer than $3 \mathrm{~s}$ but less than approximately $33 \mathrm{~s}$. He found that these atmospheric particles with diameters of $50 \mathrm{~nm}$ and $100 \mathrm{~nm}$ leaving the first humidifier further grew to $59-97.7 \mathrm{~nm}$ and $122-181 \mathrm{~nm}$ at $\sim 90 \% \mathrm{RH}$, respectively, after further humidification in the second humidifier. Such results suggest that the assumption of reaching equilibrium within 2-3 s in the first humidifier may substantially underestimate the water content and size of some atmospheric particles.

Chuang (2003) also postulated that these atmospheric particles exhibiting longer equilibrium times have an approximate accommodation coefficient in the range of $1 \times 10^{-5}$ to $4 \times 10^{-5}$ and may have a coating of organic film. Although the portion of atmospheric particles requiring longer equilibrium times in the TDMA is small in Chuang's study, organic films have been commonly found on atmospheric particles (Gill et al., 1983; Pofasi et al., 1998, 2003; Russell et al., 2002; Tervahattu et al., 2002ab; Li et al., 2003). To date, field TDMA studies have assumed that a few seconds is long enough residence time for atmospheric particles, including particles with organic coatings and water-inhibiting substances, to achieve their equilibrium size (Swietlicki et al., 2000). McMurry and Stolzenburg (1989) pointed out that the effects of organic coatings or surfactants in atmospheric particles on the equilibrium time are unknown. It is possible that an organic coating or surface-active compounds can hinder the transport of water across the particle/air interface and result in non-equilibrium growth measurements in field studies using a TDMA (Xiong et al., 1998).

\section{Conclusions}

This paper considers the issue that, due to the short residence time allowed to bring particles to equilibrium, there is a possibility of mass transfer effects complicating equilibrium hygroscopicity measurements in a TDMA in field and laboratory measurements. The equilibrium time of a few seconds is adequate for equilibrium particle growth/evaporation in typical inorganic salt particles such as $\mathrm{NaCl}$ and $\left(\mathrm{NH}_{4}\right)_{2} \mathrm{SO}_{4}$, but it may not be adequate for other particles such as those coated with organic layers. Chan and coworkers have found significant mass transfer effects in EDB hygroscopicity measurements for some inorganic salt particles such as $\mathrm{MgSO}_{4}$ (Ha and Chan, 1999; Zhang and Chan, 2000) and organic particles such as sodium pyruvate, arginine, and asparagine (Peng and Chan, 2001; Chan et al., 2005). Although particles studied in the EDB are 2 orders of magnitude larger and would take a longer equilibration time than those studied in the TDMA, these results suggest the possibility that longer equilibrium time scales may be required for TDMA measurements of these single or multicomponent particles, as discussed for glutaric acid particles earlier. Equilibrium measurements of other chemical systems with the selected residence time in TDMA measurement can be assessed by comparing the results from known studies or bulk water activity data at high RH if available.

Mass transfer effects may also complicate measurements in other types of aerosol flow-through systems that have residence times on the order of seconds for humidification or dehumidification (e.g., RH controlled nephelometry, ambientdry aerosol size spectrometer, and aerosol flow tube-FTIR system) and for the activation of particles to form clouds under supersaturated conditions. We recommend that, in addition to reporting the particle size chosen for growth studies, the residence time should also be explicitly reported and that measurements in a range of residence times be tested.

Acknowledgement. This work was funded by a HKUST grant (HKUST DAG04/05.EG17). The authors gratefully thank E. Swietlicki for his insightful comments and suggestions on the manuscript.

Edited by: A. Laaksonen

\section{References}

Aklilu, Y. A. and Mozurkewich, M.: Determination of external and internal mixing of organic and inorganic aerosol components from hygroscopic properties of submicrometer particles during a field study in the Lower Fraser Valley, Aerosol Sci. Technol., 38, 140-154, 2004.

Ames, R. B., Hand, J. L., Kreidenweis, S. M., Day, D. E., and Malm, W. C.: Optical measurements of aerosol size distributions in Great Smoky Mountains National Park: dry aerosol characterization, J. Air Waste Management Association, 50, 665-676, 2000.

Baltensperger, U., Streit, N., Weingartner, E., Nyeki, S., Prevot, S. H., Van Dingenen, R., Virkkula, A., Putaud, J.-P., Even, A., ten Brink, H., Blatter, A., Neftel, A., and Gaggeler, H. W.: Urban and rural aerosol characterization of summer smog events during the PIPAPO field campaign in Milan, Italy, J. Geophys. Res., 107(D22), 8193, doi:10.1029/2001JD001292, 2002.

Barnes, G. T.: The effects of monolayers on the evaporation of liquids, Adv. Colloid Interface Sci., 25, 89-200, 1986. 
Berg, O. H., Swietlicki, E., and Krejci, R.: Hygroscopic growth of aerosol particles in the marine boundary layer over the Pacific and Southern Oceans during the First Aerosol Characterization Experiment (ACE 1), J. Geophys. Res., 103(D13), 1653516545,1998

Bilde, M. and Svenningsson, B.: CCN activation of slightly soluble organics: Importance of small amounts of inorganic salt and particle phase, Tellus, 56B, 128-134, 2004.

Braban, C. F. and Abbatt, J. P. D.: A study of the phase behavior of internally mixed ammonium sulfate - malonic acid aerosols, Atmos. Chem. Phys., 4, 1451-1459, 2004,

\section{SRef-ID: 1680-7324/acp/2004-4-1451.}

Brechtel, F. J. and Kreidenweis, S. M.: Predicting particle critical supersaturation from hygroscopic growth measurement in the humidified TDMA. Part II: Laboratory and ambient studies, J. Atmos. Sci., 57, 1872-1887, 2000.

Brooks, S. D., Wise, M. E., Cushing, M., and Tolbert, M. A.: Deliquescence behavior of organic/ammonium sulfate aerosol, Geophys. Res. Lett., 29, 1917, doi:10.1029/2002GL014733, 2002.

Brooks, S. D., Garland, R. M., Wise, M. E., Prenni, A. J., Cushing, M., Hewitt, E., and Tolbert, M. A.: Phase changes in internally mixed maleic acid/ammonium sulfate aerosols, J. Geophys. Res., 108, 4487, doi:10.1029/2002JD003204, 2003.

Brooks, S. D., DeMott, P. J., and Kreidenweis, S. M.: Water uptake by particles containing humic materials and mixtures of humic materials with ammonium sulfate, Atmos. Environ., 38(13), 1859-1868, 2004.

Busch, B., Kandler, K., Schütz, L., and Neusüß, C.: Hygroscopic properties and water-soluble volume fraction of atmospheric particles in the diameter range from $50 \mathrm{~nm}$ to $3.8 \mu \mathrm{m}$ during LACE 98, J. Geophys. Res., 107, 8119, doi:10.1029/2000JD000228, 2002.

Buzorius, G., Zelenyuk, A., Brechtel, F., and Imre, D.: Simultaneous determination of individual ambient particle size, hygroscopicity and composition, Geophys. Res. Lett., 29, 1974, doi:10.1029/2001GL014221, 2002.

Carrico, C. M., Kreidenweis, S. M., Malm, W. C., Day, D. E., Lee, T., Carrillo, J., McMeeking, G. R., and Collett Jr., J. L.: Hygroscopic growth behavior of a carbon-dominated aerosol in Yosemite national park, Atmos. Environ., 39, 1393-1404, 2005.

Chan, C. K., Flagan, R. C., and Seinfeld, J. H.: Water activities of $\mathrm{NH}_{4} \mathrm{NO}_{3} /\left(\mathrm{NH}_{4}\right)_{2} \mathrm{SO}_{4}$ solutions, Atmos. Environ., 26, 1661$1673,1992$.

Chan, C. K., Liang, Z., Zheng, J., Clegg, S. L., and Brimblecombe, P.: Thermodynamic properties of aqueous aerosols to high supersaturation. I. Measurements of water activity of the system $\mathrm{Na}^{+}-\mathrm{Cl}^{-}-\mathrm{NO}_{3}^{-}-\mathrm{SO}_{4}^{2-}-\mathrm{H}_{2} \mathrm{O}$, Aerosol Sci. Technol., 27, 324-344, 1997.

Chan, C. K., Flagan, R. C., and Seinfeld, J. H.: In-situ study of single aqueous droplet solidification of ceramic precursors used for spray pyrolysis, J. Am. Ceram. Soc., 82(3), 646-648, 1998.

Chan, C. K., Choi, M. Y., and Zhang, Y.: Observation of mass transfer limitation in evaporation of single levitated droplets, J. Aerosol Sci., 31(S1), S989-S990, 2000.

Chan, M. N. and Chan, C. K.: Hygroscopic properties of two model humic-like substances and their mixtures with inorganics of atmospheric importance, Environ. Sci. Technol., 37, 5109-5115, 2003.
Chan, M. N., Choi, M. Y., Ng, N. L., and Chan, C. K.: Hygroscopicity of water-soluble organic compounds in atmospheric aerosols: Amino acid and biomass burning derived organic species, Environ. Sci. Technol., 39, 1555-1562, 2005.

Chen, Y. and Lee, W. M.: Hygroscopic properties of inorganic salt aerosol with surface active organic compounds, Chemosphere, 38, 2431-2448, 1999.

Chen, L. Y., Jeng, F. T., Chen, C. C., and Hsiao, T. C.: Hygroscopic behavior of atmospheric aerosol in Taipei, Atmos. Environ., 37 2069-2075, 2003.

Chuang, P. Y.: Measurement of the timescale of hygroscopic growth for atmospheric aerosols, J. Geophys. Res., 108(D9), 4282, doi:10.1029/2002JD002757, 2003.

Clegg, S. L., Brimblecombe, P., Liang, Z., and Chan, C. K.: Thermodynamic properties of aqueous aerosols to high supersaturation. II. A model of the system $\mathrm{Na}^{+}-\mathrm{Cl}^{-}-\mathrm{NO}_{3}^{-}-\mathrm{SO}_{4}^{2-}-\mathrm{H}_{2} \mathrm{O}$, Aerosol Sci Technol., 27, 345-366, 1997.

Clegg, S. L., Seinfeld, J. H., and Edney, E. O.: Thermodynamic modeling of aqueous aerosols containing electrolytes and dissolved organic compounds. II. An extended Zdanovskii-StokesRobinson approach, J. Aerosol Sci., 34, 667-690, 2003.

Cocker, D. R., Whitlock, N. E., Flagan, R. C., and Seinfeld, J. H.: Hygroscopic properties of Pasadena, California aerosol, Aerosol Sci. Technol., 35, 637-647, 2001a.

Cocker, D. R., Clegg, S. L., Flagan, R. C., and Seinfeld, J. H. The effect of water on gas-particle partitioning of secondary organic aerosol. Part I: $\alpha$-pinene/ozone system, Atmos. Environ., 35, 6049-6072, 2001b.

Cocker, D. R., Mader, B. T., Kalberer, M., Flagan, R. C., and Seinfeld, J. H.: The effect of water on gas-particle partitioning of secondary organic aerosol: II. m-xylene and 1,3,5trimethylbenzene photooxidation systems, Atmos. Environ., 35, 6073-6085, 2001c.

Cohen, M. D., Flagan, R. C., and Seinfeld, J. H.: Studies of concentrated electrolyte solutions using the electrodynamic balance: 1 . Water activities for single-electrolyte solutions, J. Phys. Chem., 91, 4563-4574, 1987.

Covert, D. S. and Heintzenberg, J.: Size distributions and chemical properties of aerosol at NY Alesund, Svalbard, Atmos. Environ., 27, 2989-2997, 1993.

Covert, D. S., Gras, J. L., Wiedensohler, A., and Stratmann, F.: Comparison of directly measured $\mathrm{CCN}$ with $\mathrm{CCN}$ modeled from the number-size distribution in marine boundary layer during ACE 1 at Cape Grim, Tasmania, J. Geophys. Res., 103, 16597 $16608,1998$.

Cruz, C. N. and Pandis, S. N.: Deliquescence and hygroscopic growth of mixed inorganic-organic atmospheric aerosol, Environ. Sci. Technol., 34, 4313-4319, 2000.

Davis, E. J.: A history of single aerosol particle levitation, Aerosol Sci. Technol., 26, 212-254, 1997.

Dick, W. D., Saxena, P., and McMurry, P. H.: Estimation of water uptake by organic compounds in submicron aerosols measured during the Southeastern Aerosol and Visibility Study, J. Geophys. Res., 105, 1471-1479, 2000.

Dua, S. K. and Hopke, P. K.: Hygroscopic growth of assorted indoor aerosols Aerosol Sci. Technol., 24, 151-160, 1996.

Dua, S. K., Hopke, P. K., and Raunemaa, T.: Hygroscopicity of diesel aerosols, Water Air Soil Pollution, 112, 247-257, 1999. 
Ferron, G. A., Karg, E., Busch, B., and Heyder, J.: Ambient particles at an urban, semi-urban and rural site in Central Europe: Hygroscopic properties, Atmos. Environ., 39, 343-352, 2005.

Gasparini, R., Li, R., and Collins, D. R.: Integration of size distributions and size-resolved hygroscopicity measured during the Houston Supersite for compositional categorization of the aerosol, Atmos. Environ., 38, 3285-3303, 2004.

Ge, Z., Wexler, A. S., and Johnston, M. V.: Multicomponent aerosol crystallization, J. Colloid Interface Sci., 183, 68-77, 1996.

Ge, Z., Wexler, A. S., and Johnston, M. V.: Deliquescence behavior of multicomponent aerosols, J. Phys. Chem., A 102, 173-180, 1998.

Gill, R. S., Graedel, T. E., and Weschler, C. J.: Organic films on atmospheric aerosol particles, fog droplets, cloud droplets, raindrops, and snowflakes, Rev. Geophys., 22, 903-920, 1983.

Gysel, M., Weingartner, E., and Baltensperger, U.: Hygroscopicity of aerosol particles at low temperatures. 2. Theoretical and experimental hygroscopic properties of laboratory generated aerosols, Environ. Sci. Technol., 36(1), 63-68, 2002.

Gysel, M., Nyeki, S., Weingartner, E., Baltensperger, U., Giebl, H., Hitzenberger, R., Petzold, A., and Wilson, C. W.: Properties of jet engine combustion particles during the PartEmis experiment: Hygroscopicity at subsaturated conditions, Geophys. Res. Lett., 30, 1566, doi:10.1029/2003GL0.16896, 2003.

Gysel, M., Weingartner, E., Nyeki, S., Paulsen, D., Baltensperger, U., Galambos, I., and Kiss, G.: Hygroscopic properties of water-soluble matter and humic-like organics in atmospheric fine aerosol, Atmos. Chem. Phys., 4, 35-50, 2004,

SRef-ID: 1680-7324/acp/2004-4-35.

$\mathrm{Ha}, \mathrm{Z}$. and Chan, C. K.: The water activities of $\mathrm{MgCl}_{2}, \mathrm{Mg}\left(\mathrm{NO}_{3}\right)_{2}$, $\mathrm{MgSO}_{4}$, and their mixtures, Aerosol Sci Technol., 31, 154-169, 1999.

Hameri, K., Vakeva, M., Hansson, H.-C., and Laaksonen, A.: Hygroscopic growth of ultrafine ammonium sulfate aerosol measured using an ultrafine tandem differential mobility analyzer, J. Geophys. Res., 105, 22 231-22 242, 2000.

Hameri, K., Laaksonen, A., Vakeva, M., and Suni, T.: Hygroscopic growth of ultrafine sodium chloride particles, J. Geophys. Res., 106, 20749-20 757, 2001a.

Hameri, K., Vakeva, M., Aalto, P. P., Kulmala, M., Swietlicki, E., Zhou, J.C., Seidl, W., Becker, E., and O'Dowd, C. D.: Hygroscopic and CCN properties of aerosol particles in boreal forests, Tellus, 53B, 359-379, 2001b.

Hameri, K., Charlson, R., and Hansson, H.C.: Hygroscopic properties of mixed ammonium sulfate and carboxylic acid particles, AIChE, 48, 1309-1316, 2002.

Hand, J. L., Ames, R. B., Kreidenweis, S. M., Day, D. E., and Malm, W. C.: Estimates of particle hygroscopicity during the Southeastern Aerosol and Visibility Study, J. Air Waste Management Association, 50, 677-685, 2000.

Hansson, H. C., Rood, M. J., Koloutsou-Vakakis, S., Hameri, K., Orsini, D., and Wiedensohler, A.: $\mathrm{NaCl}$ aerosol particle hygroscopicity dependence on mixing with organic compounds, J. Atmos. Chem., 31(3), 321-346, 1998.

Hitzenberger, R., Berner, A., Dusek, U., and Alabashi, R.: Humidity-dependent growth of size-segregated aerosol samples, Aerosol Sci. Technol., 27, 116-130, 1997.

$\mathrm{Hu}$, J. H. and Abbatt, J. P. D.: Reaction probabilities for $\mathrm{N}_{2} \mathrm{O}_{5}$ hydrolysis on sulfuric acid and ammonium sulfate aerosols at room temperature, J. Phys. Chem. A, 101, 871-878, 1997.

Johnson, G. R., Ristovski, Z., and Morawska, L.: Method for measuring the hygroscopic behavior of lower volatility fractions in an internally mixed aerosol, J. Aerosol Sci., 35, 443-455, 2004.

Kanakidou, M., Seinfeld, J. H., Pandis, S. N., Barnes, I., Dentener, F. J., Facchini, M. C., van Dingenen, R., Ervens, B., Nenes, A., Nielsen, C. J., Swietlicki, E., Putaud, J. P., Balkanski, Y., Fuzzi, S., Horth, J., Moortgat, G. K., Winterhalter, R., Myhre, C. E. L., Tsigaridis, K., Vignati, E., Stephanou, E. G., and Wilson, J.: Organic aerosol and global climate modelling: A review, Atmos. Chem. Phys., 5, 1053-1123, 2005,

\section{SRef-ID: 1680-7324/acp/2005-5-1053.}

Kerminen, V. M.: The effects of particle chemical character and atmospheric processes on particle hygroscopic properties, J. Aerosol Sci., 28, 121-132, 1997.

Kreidenweis, S. M., Koehler, K., DeMott, P., Prenni, A. J., Carrico, C. and Ervens, B.: Water activity and activation diameters from hygroscopic data - Part 1: Theory and application to inorganic salts, Atmos. Chem. Phys., 5, 1357-1370, 2005,

SRef-ID: 1680-7324/acp/2005-5-1357.

Kreisberg, N. M., Stolzenburg, M. R., Hering, S. V., Dick, W. D., and McMurry, P. H.: A new method for measuring the dependence of particle size distributions on relative humidity, with application to the Southeastern Aerosol and Visibility Study, J. Geophys. Res., 106(D14), 14 935-14 949, 2001.

Li, J., Posfai, M., Hobbs, P. V., and Buseck, P. R.: Individual aerosol particles from biomass burning in southern Africa: 2 Compositions and aging of inorganic particles, J. Geophys. Res., 108(D13), 8484, doi:10.1029/2002JD002310, 2003.

Liu, B. Y. H., Pui, D. Y. H., Whitby, K. T., Kittelson, D. B., Kousaka, Y., and McKenzie, R. L.: The aerosol mobility chromatograph: a new detector for sulfuric acid aerosols, Atmos. Environ., 12, 99-104, 1978.

Marcolli, C., Luo, B. P., and Peter, T.: Mixing of the organic aerosol fractions: Liquids as the thermodynamically stable phases, J. Phys. Chem. A, 108, 2216-2224, 2004.

Martin, S. T.: Phase transitions of aqueous atmospheric particles, Chem. Rev., 100, 3403-3453, 2000.

Martin, S. T., Hung, H. M., Park, R. J., Jacob, D. J., Spurr, R. J. D., Chance, K. V., and Chin, M.: Effects of the physical state of tropospheric ammonium-sulfate-nitrate particles on global aerosol direct radiative forcing, Atmos. Chem. Phys., 4, 183-214, 2004, SRef-ID: 1680-7324/acp/2004-4-183.

Massling, A., Wiedensohler, A., Busch, B., Neusüss, C., Quinn, P., Bates, T., and Covert, D.: Hygroscopic properties of different aerosol types over the Atlantic and Indian Oceans, Atmos. Chem. Phys., 3, 1377-1397, 2003,

SRef-ID: 1680-7324/acp/2003-3-1377.

McMurry, P. H. and Stolzenburg, M. R.: On the sensitivity of particle size to relative humidity for Los Angeles aerosols, Atmos. Environ., 23, 497-507, 1989.

McMurry, P. H., Litchy, M., Huang, P. F., Cai, X. P., Turpin, B. J., Dick, W. D., and Hanson, A.: Elemental composition and morphology of individual particles separated by size and hygroscopicity with the TDMA, Atmos. Environ., 30, 101-108, 1996.

Mikhailov, E., Vlasenko, S., Niessner, R., and Poschl, U.: Interaction of aerosol particles composed of protein and salts with water vapor: hygroscopic growth and microstructrual rearrangement, Atmos. Chem. Phys., 4, 323-350, 2004, 
SRef-ID: 1680-7324/acp/2004-4-323.

Ming, Y. and Russell, L. M.: Thermodynamic equilibrium of organic-electrolyte mixtures in aerosol particles, AIChE, 48, 1331-1348, 2002.

Mochida, M. and Kawamura, K.: Hygroscopic properties of levoglucosan and related organic compounds characteristics to biomass burning aerosol particles, J. Geophys. Res., 109, D21202, doi:10.1029/2004JD004962, 2004.

Nessler, R., Bukowiecki, N., Henning, S., Weingartner, E., Calpini, B., and Baltensperger, U.: Simultaneous dry and ambient measurement of aerosol size distributions at the Jungfraujoch, Tellus, 53B, 808-819, 2003.

Pagels, J., Strand, M. Rissler, J., Szpila, A., Gudmundsson, A., Bohgard, M., Lillieblad, L., Sanati, M., and Swietlicki, E. Characteristics of aerosol particles formed during grate combustion of moist forest residue, Atmos. Environ., 34, 1043-1059, 2003.

Pandis, S. N., Wexler, A. S., and Seinfeld, J. H.: Dynamics of tropospheric aerosols, J. Phys. Chem., 99, 9646-9659, 1995.

Pant, A., Fok, A., Parsons, M. T., Mak, J., and Bertram, A. K.: Deliquescence and crystallization of ammonium sulfate-glutaric acid and sodium chloride-glutaric acid particles, Geophys. Res. Lett., 31, L12111, doi:10.1029/2004GL020025, 2004.

Parsons, M. T., Mak, J., Lipetz, S. R., and Bertram, A. K.: Deliquescence of malonic, succinic, glutaric, and adipic acid particles, J. Geophys. Res., 109, D06212, doi:10.1029/2003JD004075, 2004.

Peng, C. and Chan, C. K.: The water cycles of water soluble organic salts of atmospheric importance, Atmos. Environ., 35, 11831192,2001

Peng, C., Chan, M. N., and Chan, C. K.: The hygroscopic properties of dicarboxylic and multifunctional acids: Measurements and UNIFAC predictions, Environ. Sci. Technol., 35, 4495-4501, 2001.

Petaja, T., Kerminen, V. M., Hameri, K., Vaattovaara, P., Joutsensaari, J., Junkermann, W., Laaksonen, A., and Kulmala, M.: Effects of $\mathrm{SO}_{2}$ oxidation on ambient aerosol growth in water and ethanol vapours, Atmos. Chem. Phys., 5, 767-779, 2005, SRef-ID: 1680-7324/acp/2005-5-767.

Pitchford, M. L. and McMurry, P. H.: Relationship between measured water vapor growth and chemistry of atmospheric aerosol for Grand Canyon, Arizona, in winter 1990, Atmos. Environ., 28, 827-839, 1994

Posfai, M., Xu, H. F., Anderson, J. R., and Buseck, P. R.: Wet and dry sizes of atmospheric aerosol particles: an AFM-TEM study, Geophys. Res. Lett., 25, 1907-1910, 1998.

Posfai, M., Simonics, R., Li, J., Hobbs, P. V., and Buseck, P. R.: Individual aerosol particles from biomass burning in southern Africa: 1. Compositions and size distributions of carbonaceous particles, J. Geophys. Res., 108(D13), 8483, doi:10.1029/2002JD00291, 2003.

Prenni, A. J., DeMott, P. J., Kreidenweis, S. M., Sherman, D. E., Russell, L. M., and Ming, Y.: The effect of low molecular weight dicarboxylic acids on cloud formation, J. Phys. Chem. A, 105, 11 240-11 248, 2001.

Prenni, A. J., DeMott, P. J., and Kreidenweis, S. M.: Water uptake of internally mixed particles containing ammonium sulfate and dicarboxylic acids, Atmos. Environ., 37(30), 4243-4251, 2003.

Rader, D. J. and McMurry, P. H.: Application of the tandem differential mobility analyzer for studies of droplet growth or evaporation, J. Aerosol. Sci., 17, 771-787, 1986.
Ray, A. K., Johnson, R. D., and Souyri, A.: Dynamic behavior of single glycerol droplets in humid air streams, Langmuir, 5, 133$140,1989$.

Richardson, C. B. and Spann, J. F.: Measurement of the water cycle in a levitated ammonium sulfate particle, J. Aerosol Sci., 5, 563571, 1984.

Rissler, J., Swietlicki, E., Zhou, J., Roberts, G. C., Andreae, M. O., Gatti, L. V., and Artaxo, P.: Physical properties of the submicrometer aerosol over the Amazon rain forest during the wetto-dry season transition - Comparison of modeled and measured CCN concentrations, Atmos. Chem. Phys., 4, 2119-2143, 2004, SRef-ID: 1680-7324/acp/2004-4-2119.

Ristovski, Z. D., Morawska, L., Hitchins, J., and Barron, W.: Influence of the sheath air humidity on the SMPS measurements of hygroscopic aerosols, J. Aerosol. Sci., 29, S327-S328, 1998.

Roberts, G. C., Artaxo, P., Zhou, J., Swietlicki, E., and Andreae, M. O.: Sensitivity of CCN spectra on chemical and physical properties of aerosol: A case study from the Amazon Basin, J. Geophys. Res., 107, D20, 8070, doi:10.1029/2001JD0000583, 2002.

Russell, L. M., Maria, S. F., and Myneni, S. C. B.: Mapping organic coatings on atmospheric particles, Geophys. Res. Lett., 29(D16), doi:10.1029/2002GL014874, 2002.

Saathoff, H., Naumann, K.-H., Schnaiter, M., Schock, W., Mohler, O., Schurath, U., Weingartner, E., Gysel, M., and Baltensperger, U.: Coating of soot and $\left(\mathrm{NH}_{4}\right)_{2} \mathrm{SO}_{4}$ particles by ozonolysis products of $\alpha$-pinene, J. Aerosol Sci., 34, 1297-1321, 2003.

Santarpia, J. L., Li. R. J., and Collins, D. R.: Direct measurement of the hydration state of ambient aerosol populations, J. Geophys. Res., 109, D18209, doi:10.1029/2004JD004653, 2004.

Santarpia, J. L., Gasparini, R., Li, R. J., and Collins, D. R.: Diurnal variations in the hygroscopic growth cycles of ambient aerosol populations, J. Geophys. Res., 110, D03206, doi:10.1029/2004JD005279, 2005.

Saxena, P., Hildemann, L. M., McMurry, P. H., and Seinfeld, J. H.: Organics alter hygroscopic behavior of atmospheric particles, J. Geophys. Res., 100(D9), 18 755-18 770, 1995.

Seinfeld, J. H.: Atmospheric Chemistry and Physics of Air Pollution, Wiley, New York, 1986.

Sjogren, S., Weingartner, E., Baltensperger, U., Cubison, M., Topping, D., McFiggans, G., and Coe, H.: Hygroscopic growth and times of phase change for aerosol mixtures of inorganic salts and organic substances, Abstracts of the European Aerosol Conference 2004, J. Aerosol Sci., 35, S497-S498, 2004.

Speer, R. E., Barnes, H. M., and Brown, R.: An instrument for measuring the liquid water content of aerosols, Aerosol Sci. Technol., 27, 50-61, 1997.

Stanier, C. O., Khlystov, A. Y., Chan, W. R., Mandiro, M., and Pandis, S. N.: A method for the in situ measurement of fine aerosol water content of ambient aerosols: The dry-ambient aerosol size spectrometer (DAASS), Aerosol Sci. Technol., 38(S1), 215-228, 2004.

Svenningsson, B., Hansson, H.-C., and Wiedensohler, A.: Hygroscopic growth of aerosol particles in the Po Valley, Tellus, 44B, 556-569, 1992.

Svenningsson, B., Hansson, H.-C., Wiedensohler, A., Nonne, K., Orgen, J., Hallberg, A., and Colvile, R.: Hygroscopic growth of aerosol particles and its influence on nucleation scavenging in clouds: experimental results from Kleiner Feldberg, J. Atmos. Chem., 19, 129-152, 1994. 
Svenningsson, B., Hansson, H.-C., Martinsson, B., Wiedensohler, A., Swietlicki, E., Cederfelt, S.-L., Wendisch, M., Bower, K. N., Choularton, T. W., and Colvile, R. N.: Cloud droplet nucleation scavenging in relation to the size and hygroscopic behavior of aerosol particles, Atmos. Environ., 31, 2463-2475, 1997.

Swietlicki, E., Zhou, J., Berg, O. H., Martinsson, B. G., Frank, G., Cederfelt, S. I., Dusek, U., Berner, A., Birmili, W., Wiedensohler, A., Yuskiewicz, B., and Bower, K. N.: A closure study of sub-micrometer aerosol particle hygroscopic behaviour, Atmos. Res., 50, 205-240, 1999.

Swietlicki, E., Zhou, J., Covert, D. S., Hameri, K., Busch, B., Vakeva, M., Dusek, U., Berg, O. H., Wiedensohler, A., Aalto, P., Mäkelä, J., Martinsson, B. G., Papaspiropoulos, G., Mentes, B., Frank, G., and Stratmann, F.: Hygroscopic properties of aerosol particles in the north-eastern Atlantic during ACE-2, Tellus, 52B, 201-227, 2000.

Tang, I, N. and Munkelwitz, H. R.: Composition and temperaturedependence of the deliquescence properties of hygroscopic aerosols, Atmos. Environ., 27, 467-473, 1993.

Tang, I, N. and Munkelwitz, H. R.: Water activities, densities, and refractive-indexes of aqueous sulfates and sodiumnitrate droplets of atmospheric importance, J. Geophys. Res., 99, 18 801-18 808, 1994.

ten Brink, H. M., Khlystov, A., Kos, G. P.A., Tuch, T., Roth, C., and Kreyling, W.: A high-flow humidograph for testing the water uptake by ambient aerosol, Atmos. Environ., 34, 4291-4300, 2000.

Tervahattu, H., Juhanoja, J., and Kupiainen, K.: Identification of an organic coating on marine aerosol particles by TOF-SIMS, J. Geophys. Res., 107(D16), doi:10.1029/2001JD001403, 2002a.

Tervahattu, H., Hartonen, K., Kerminen, V. M., Kupiainen, K., Aarnio, P., Koskentalo, T., Tuck, A. F., and Vaida, V.: New evidence of an organic layer on marine aerosols, J. Geophys. Res., 107(D17), doi:10.1029/2000JD000282, 2002b.

Topping, D. O., McFiggans, G. B., and Coe, H.: A curved multi-component aerosol hygroscopicity model framework: 2including organics, Atmos. Chem. Phys., 5, 1223-1242, 2004,

SRef-ID: 1680-7324/acp/2005-5-1223.

Vakeva, M., Kulmala, M., Stratmann, F., and Hameri, K.: Field measurements of hygroscopic properties and state of mixing of nucleation mode particles, Atmos. Chem. Phys., 2, 55-66, 2002a, SRef-ID: 1680-7324/acp/2002-2-55.
Vakeva, M., Hameri, K., and Aalto, P. P.: Hygroscopic properties of nucleation mode and Aitken mode particles during nucleation bursts and in background air on the west coast of Ireland, J. Geophys. Res., 107 (D19), 8104, doi:10.1029/2000JD0000176, 2002b.

Virkkula, A., Van Dingenen, R., Raes, F., and Hjorth, J.: Hygroscopic properties of aerosol formed by oxidation of limonene, alpha-pinene, and beta-pinene, J. Geophys. Res., 104, 35693579, 1999.

Weingartner, E., Burtscher, H., and Baltensperger, U.: Hygroscopic properties of carbon and diesel soot particle, Atmos. Environ., 31, 2311-2327, 1997.

Weingartner, E., Gysel, M., and Baltensperger, U.: Hygroscopicity of aerosol particles at low temperatures. 1. New low-temperature H-TDMA instrument: setup and first applications, Environ. Sci. Technol., 36, 55-62, 2002.

Wise, M. E., Surratt, J. D., Curtis, D. B., Shilling, J. E., and Tolbert, M. A.: Hygroscopic growth of ammonium sulfate/dicarboxylic acids, J. Geophys. Res., 108(20), 4638, doi:10.1029/2003JD003775, 2003.

Xiong, J. Q., Zhong, M. H., Fang, C. P., Chen, L. C., and Lippmann, M.: Influence of organic films on hygroscopicity of ultrafine sulfuric acid aerosol, Environ. Sci. Technol., 32, 3536-3541, 1998.

Zhang, X. Q., McMurry, P. H., Hering, S. V., and Casuccio, G. S.: Mixing characteristics and water content of submicron aerosols measured in Los Angeles and at the Grand Canyon, Atmos. Environ., 27, 1593-1607, 1993.

Zhang, Y. and Chan, C. K.: Study of contact ion pairs of supersaturated magnesium sulfate solutions using Raman scattering of levitated single droplets, J. Phys. Chem. A, 104, 1911-1916, 2000.

Zhou, J. C., Swietlicki, E., Berg, O. H., Aalto, P. P., Hameri, K., Nilsson, E. D., and Leck, C.: Hygroscopic properties of aerosol particles over the central Arctic Ocean during summer, J. Geophys. Res., 106(D23), 32 111-32 123, 2001.

Zhou, J. C., Swietlicki, E., Hansson, H. C., and Artaxo, P.: Submicrometer aerosol particle size distribution and hygroscopic growth measured in the Amazon rain forest during the wet reason, J. Geophys. Res., 107(D20), 8055, doi10.1029/200JD000203, 2002. 